\title{
積層ゴムで支持した塔状免震建物の終局挙動に関する振動台実験 積層ゴム破壊時の詳細挙動

\author{
SHAKING TABLE TESTS ON THE ULTIMATE BEHAVIOR OF SLENDER BASE-ISOLATED \\ BUILDINGS SUPPORTED BY LAMINATED RUBBER BEARINGS \\ Detailed behavior on fracture of laminated rubber bearings
} \\ 高岡栄治*, 二村有則 ${ }^{* *}$, 竹中 康 雄*** \\ Eiji TAKAOKA, Arinori NIMURA and Yasuo TAKENAKA
}

\begin{abstract}
This paper describes the results of shaking table tests on a slender base-isolated building model supported by four laminated rubber bearings to clarify the ultimate behavior when bearing fracture occurs. The results of the tests indicate that the ultimate behavior of the base-isolated building is roughly classified into two types; one is caused by buckling fracture of the bearing, and the other is a result of tensile fracture of the bearing. In the buckling type, one of the standards for judging the occurrence of buckling fracture is that the lateral deformation exceeds the value corresponding to the diameter of the bearing, and the aspect ratio of the building does not have much effect on the ultimate behavior. In the tensile type, tensile deformation becomes higher with an increase in aspect ratio, and the ultimate input level does not decrease. The building has a safety margin to fracture even if the aspect ratio becomes larger.
\end{abstract}

Keywords : Base-isolated building, Laminated rubber bearing, Aspect ratio, Ultimate behavior, Shaking table test 免震建物、積層ゴム、塔状比、終局挙動、振動台実験

\section{1.はじめに}

構造物の限界状態における終局挙動を把握することは、現状の設 計が有する安全余裕度を定量的に評価するためにも重要な課題であ る。免震建物では免震層を構成する積層ゴム等の免震部材の破壊を もって限界状態と捉えることができる。上部構造の運動と積層ゴム の破壊形式に着目寸ると、免震建物の終局挙動は、免震層の水平変 形が大きくなり積層ゴムが圧縮荷重によって座屈的に破壊するタイ プ、上部構造にロッキング振動が生じて浮き上がり、積層ゴムが引 張り破断するタイプに大別される。従来から免震構造の主たる適用 対象とされてきた塔状比（建物の高さと幅の比）の小さい中低層の 免震建物では、転倒モーメントが小さいため大入力時においても積 層ゴムに引張り力が生じにくく、前者のタイプが終局挙動として想 定される。一方、近年、免震構造の適用が増加している塔状比の大 きい高層建物では、転倒モーメントの影響により、大入力時には積 層ゴムに引張り力あるいは過大な圧縮荷重が生じる可能性が高い。 その結果、後者のタイプが終局挙動として生じることが予想される が、その他にも前者のタイプや両タイプが混在する場合などもあり、 非常に複雑な終局挙動を呈する 1) 5)。

免震建物の終局挙動の確認を目的とし、これまでにいくつかの振 動台実験が実施されている。原子炉建屋模型を対象とした振動台実 験では、積層ゴムが破断するまでの実験も行なわれている 6)。しか
し、塔状比が小さい偏平な建物を対象としていること、積層ゴムの 座屈的な破壊が考慮されてないこと等から、終局挙動について包括 的な結論は得られていない。また、塔状比が $4 \sim 6$ 程度の試験体を 対象とした振動台実験もいくつか実施されているが、終局挙動では なく大入力に対する挙動の確認を主たる目的としている 7) 9)。これ に対して、筆者らは、塔状の縮小免震建物模型を用いて積層ゴムが 破壊するまでの振動台実験を実施し、積層ゴムの形状・面圧と塔状 比が終局挙動に与える影響について分析した ${ }^{1)}$ ５)。しかし、積層ゴ ムが破壊する前の入力レベルでの挙動に着目したため、積層ゴム破 壊時の挙動については検討が不十分であり、現象が明らかにされて いない。以上の背景の下、本論では、積層ゴムで支持した塔状免震 建物の振動台実験の結果について、積層ゴム破壊時における終局挙 動に着目して詳細な分析を行った。

\section{2. 振動台実験 1)}

塔状免震建物の終局挙動を明らかにするために実施した振動台 実験の概要について述べる。試験体は、4 体の積層ゴムで支持され た総質量 1620 ton の剛な塔状免震建物を原型とし、これを表 1 に示 寸相似則に従って $1 / 9$ に縮尺した縮小模型である。試験体を図 1 に 示す。上部構造は鉄筋コンクリート製の重鍾 4 個を PC 鋼棒で締結 したもので (以下重錘)、総質量は 19.6ton（実測）である。積層ゴ

\footnotetext{
* 鹿島技術研究所 主任研究員 ·博士 $($ 工学 $)$

** 鹿島技術研究所 主任研究員・修士 (工学)

*** 鹿島小堀研究室 室次長 · 修士 (工学)
}

Senior Research Engineer, Kajima Technical Research Institute, Kajima Corporation, Dr. Eng.

Senior Research Engineer, Kajima Technical Research Institute, Kajima Corporation, M. Eng.

Assistant Director, Kobori Research Complex, Kajima Corporation, M. Eng. 
ムは鉛プラグ入り積層ゴム (LRB) 4 体を用いた。終局挙動に影響 を与える実験要因として、重錘の塔状比 $\mathrm{H} / \mathrm{B}$ (建物高さ $\mathrm{H} ・$ 積層ゴ 么軸芯間距離 $\mathrm{B}) 、$ 積層ゴムの形状 $(コ ゙ ム$ 総厚 $\mathrm{h}$ ・直径 $\mathrm{D}) \cdot$ 面圧 $\sigma$ を選定した。表 2 に、各要因のケースとそれらを組み合わせた実験 ケースを示す。免震周期 $T$ はそれぞれ 1.33 秒及び 1.09 秒であり、 原型に換算するとそれぞれ 4.00 秒及び 3.27 秒である。また、表 3 に積層ゴムの形状諸元を示す。入力地震動は BCJ-L2 波を相似則に 従い時間軸を $1 / 3$ に縮小して用いた。入力方向は水平 1 方向とし、 加振レベルは原波を基準として 0.5 倍、1.0 倍…と 0.5 倍刻夕で積 層ゴムが破壊するまで振幅を拡幅させた。以下では加振レベルを倍 率 $\times$ L2 で表記する。重鍾の加速度と積層ゴムの変形と荷重を測定し た他、積層ゴムの変形状態を振動台上に設置したビデオカメラによ って記録した。実験結果より、積層ゴム A（あるいは B）の荷重及 び変形として、負側（あるいは正側）の 2 つの積層ゴムの荷重の和 及び変形の平均值を求めた。

\section{3. 実験結果}

\section{1 破壊形式}

いずれのケースについても、加振レベルの増大に伴い積層ゴムに 過大な水平変形と引張り変形又は沈み込み変形が生じ、積層ゴムの

表 1 相似則 $(\lambda=9)$

\begin{tabular}{|c|c|c|c|}
\hline 項目 & (模型 $) /($ 原型 $)$ & 項目 & (模型 $) /($ 原型 $)$ \\
\hline 時間 $($ 周期 $)$ & $1 / \sqrt{ }$ ) & 力 (重量) & $1 / \lambda^{2}$ \\
\hline 加速度 & 1 & 剛性 & $1 / \lambda$ \\
\hline 速度 & $1 / \sqrt{ } \lambda$ & 応力度 & 1 \\
\hline 変位 $($ 長さ $)$ & $1 / \lambda$ & ひずみ度 & 1 \\
\hline
\end{tabular}

表 2 実験ケース

\begin{tabular}{|c|c|c|c|c|}
\hline & \multicolumn{2}{|c|}{ 塔状比（H/B） } & \multirow{2}{*}{$\begin{array}{c}T \\
(\mathrm{~s}) \\
\end{array}$} \\
\hline & & 4 & 6 & \\
\hline \multirow{2}{*}{$\begin{array}{c}\text { 積層ゴム } \\
\text { 形状・面圧 } \\
\mathrm{h}=22 \mathrm{~mm}\end{array}$} & $\begin{array}{c}\mathrm{D}=90 \mathrm{~mm} 、 \mathrm{~S}_{2}=4 \\
\sigma=7.55 \mathrm{MPa}\end{array}$ & ケース(1) & ケース(3) & 1.33 \\
\hline & $\begin{array}{c}\mathrm{D}=110 \mathrm{~mm} 、 \mathrm{~S}_{2}=5 \\
\sigma=5.05 \mathrm{MPa}\end{array}$ & ケース(2) & ケース(4) & 1.09 \\
\hline
\end{tabular}

表 3 積層ゴムの形状諸元

\begin{tabular}{|c|c|c|c|}
\hline \multicolumn{2}{|c|}{ 実験ケース } & (1)、(3) & (2)、(4) \\
\hline 直径 D(外径) & $(\mathrm{mm})$ & 90 & 110 \\
\hline 鉛径 & $(\mathrm{mm})$ & 18 & 22 \\
\hline ゴム 1 層厚 $\mathrm{t}$ & $(\mathrm{mm})$ & \multicolumn{2}{|c|}{1.0} \\
\hline ゴム総厚 h & $(\mathrm{mm})$ & \multicolumn{2}{|c|}{22} \\
\hline 中間鋼板厚 & $(\mathrm{mm})$ & \multicolumn{2}{|c|}{1} \\
\hline \multicolumn{2}{|c|}{1 次形状係数 $\mathrm{S}_{1}(\mathrm{D} / 4 \mathrm{t})$} & 22.5 & 27.5 \\
\hline \multicolumn{2}{|c|}{2 次形状係数 $\mathrm{S}_{2}(\mathrm{D} / \mathrm{h})$} & 4 & 5 \\
\hline 支持質量 & (ton) & \multicolumn{2}{|c|}{4.9} \\
\hline 静止時面圧 & (MPa) & 7.55 & 5.05 \\
\hline
\end{tabular}

表 4 終局加振レベルと破壊形式

\begin{tabular}{|c|c|c|c|c|c|}
\hline \multicolumn{2}{|c|}{ ケース } & 1 & $(2)$ & $(3$ & $(4)$ \\
\hline 加振レベル $(\times \mathrm{L} 2)$ & 3.0 & 4.5 & 3.0 & 4.0 \\
\hline \multirow{2}{*}{$\begin{array}{c}\text { 破壊 } \\
\text { 形式 }\end{array}$} & 積層ゴム $\mathrm{A}$ & 座屈 & 座屈 & 座屈 & 引張 \\
\cline { 2 - 6 } & 積層ゴム $\mathrm{B}$ & 座屈 & 引張 & 座屈 & 座屈 \\
\hline
\end{tabular}

破壊により終局に至った。表 4 に、積層ゴムが破壊した終局加振レ ベルと積層ゴムの破壊形式を示す。積層ゴム直径が $90 \mathrm{~mm}$ のケース (1)、(3)では、加振レベル $3.0 \times \mathrm{L} 2$ において圧縮荷重下で積層ゴムに 破壊が生じた(以下座屈破壞と称す)。110 $\mathrm{mm}$ のケース(2)、(4)では、 加振レベル $4.0 \times \mathrm{L} 2$ 又は $4.5 \times \mathrm{L} 2$ において、一方の積層ゴムに引張 り破断が生じ、その直後にもう一方の積層ゴムに座屈破壊が生じた。

\section{2 応答最大値}

各種応答の最大值と加振レベルの関係より、終局までの重鏵と積 層ゴムの挙動の概略を調べた。図 2 に、重鏵上端水平加速度、重錘 重心水平加速度、免震層水平変形、積層ゴム鉛直变形の最大值と加

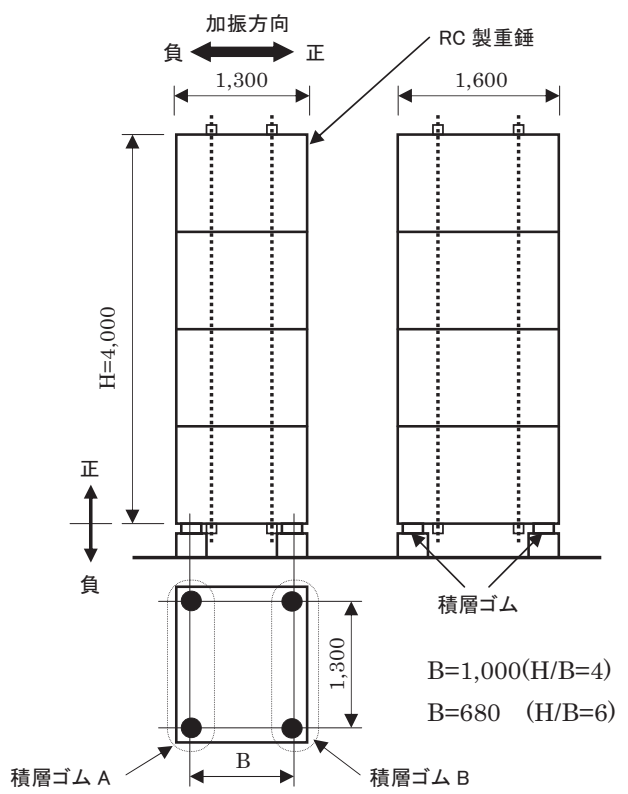

図 1 振動台実験の試験体
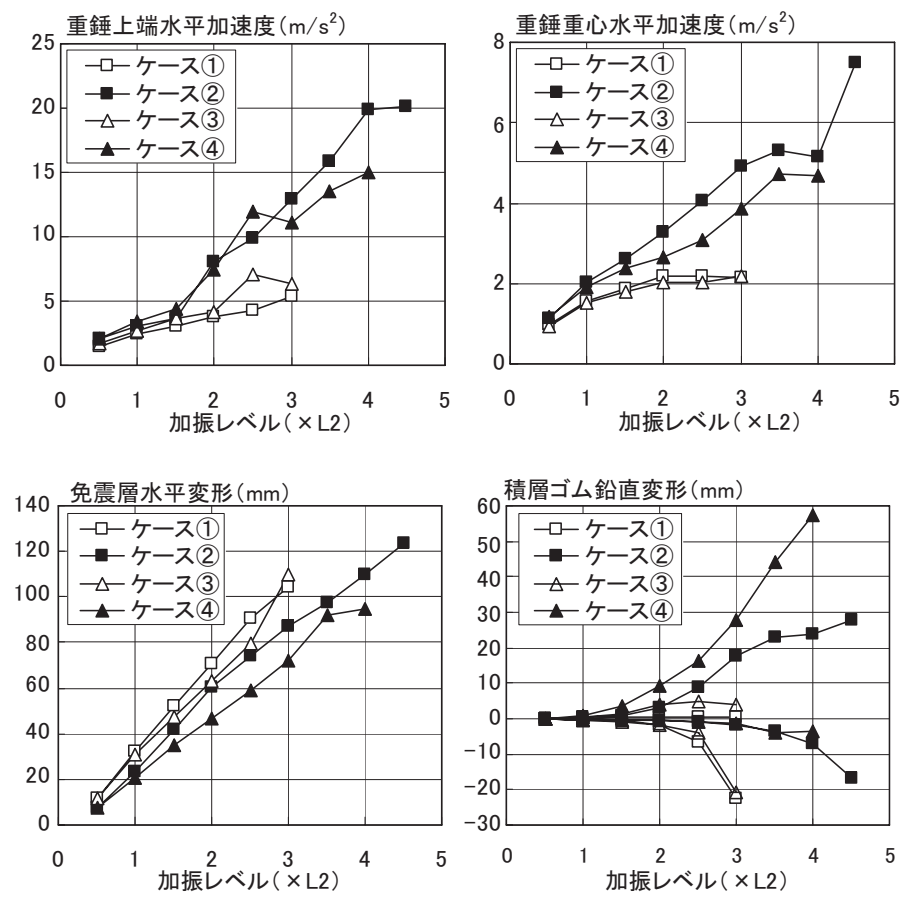

図 2 応答最大值 
振レベルとの関係を示す。横軸は加振レベルで、それぞれ終局加振 レベルまでをプロットしている。なお、積層ゴム鉛直変形の最大值 は、引張り変形を正側に、沈み込み変形を負側にそれぞれ示してい る。これらの図より以下のことが指摘できる。

重錘上端水平加速度 : ケース (2)、(4)では $2.0 \times \mathrm{L} 2$ において、ケース (3)では $2.5 \times \mathrm{L} 2$ において加速度が急激に増加している。これは積層 ゴムに引張り変形が生じて重錘の片側が浮き上がり、再び着地した 際に生じる衝撃によるものである。ケース(2)、(4)では、それ以降加 振レベルに対する加速度の増加率が大きくなり、加速度はケース (1)、 (3)の值と比べて大きくなる。

重鍾重心水平加速度 : ケース(2)の終局加振レベルを除くと、加速度 は加振レベルに対して概ね滑らかに増加している。加速度が急増す る加振レベルは認められず、重心には着地に伴う大きな加速度が生 じていない。また、ケース(1)、(3)では $2.0 \times$ L2 において、ケース(2)、 (4)では $3.5 \times \mathrm{L} 2$ において、それぞれ加速度が頭打ちとなる。ケース (1)、(3)の方がケース (2)、(4)よりも加速度が小さいが、ケース (1)、(3) の方が積層ゴムの直径が小さく水平剛性が小さいため、免震周期が より長くなっているためである。積層ゴム直径が等しいケースの比 較では、塔状比の大きい方が加速度が小さい。ただし、直径 $90 \mathrm{~mm}$ のケース(1)、(3)の加速度の差は僅かである。

免震層水平変形 : 免震層水平変形は加振レベルの増大に伴いほぼ線 形的に増大している。ケース(4)を除き、終局加振レベルの水平変形 は、各ケースの直径に相当する変形を上回っている。ケース (1)、(3) の方がケース (2)、(4)よりも水平変形が大きいが、上記と同様にケー ス (1)、(3)の免震周期がより長くなっているためである。積層ゴム直 径が等しいケースの比較では、塔状比の大きい方が水平変形が小さ い。ただし、直径 $90 \mathrm{~mm}$ のケース (1)、(3)の水平変形の差は小さい。 積層ゴム鉛直変形 : ケース (2)、(4)では、 $1.5 \times \mathrm{L} 2$ で初めて引張り変 形が生じ、加振レベルの増大に伴い変形が増加する。塔状比の大き いケース (4)では、変形が 2 次曲線的に増加し、終局加振レベルでの 引張り変形は $57 \mathrm{~mm}$ である。ケース (3)でも $1.5 \times \mathrm{L} 2$ で引張り変形が 初めて生じるが、引張り変形は増加せず、大きな沈み込み変形が生 じる。一方、ケース(1)では、引張り変形は生じず、沈み込み変形の みが生じている。

以下に各ケースの終局加振レベルまでの挙動を破壊形式毎にま とめて示す。

ケース (1)、(3) (座屈破壊) : ケース (1)では沈み込み変形のみが生じて おり、終局まで並進運動が支配的である。ケース (3)では引張り変形 が生じるが、変形量は小さく重錘の運動は概衫並進的である。重錘 上端・重心ともに、水平加速度は終局まで小さい值に保たれており、 免震効果が維持されている。両者の応答最大值の差は小さく、ケー ス (3)で引張り変形が生じたことを除けば、両者の挙動は概ね同一の ものとして分類される。

ケース(2)、(4)（引張り破断）: 加振レベルが大きくなると、積層ゴム の引張り変形が大きくなり、重錘の併進運動とともに回転運動が生 じる。特にケース(4)では引張り変形が 2 次曲線的に増大し、回転運 動が顕著になる。重錘上端では、重錘着地時の衝撃に伴い、重心と 比較して極めて大きな加速度が生じる。両者の応答最大值には有意 な差が認められる。特に引張り変形の差が大きく、両者の挙動は大 きく異なっている。

\section{3 積層ゴム破壊時詳細挙動}

各ケースについて、積層ゴムの破壊が生じた終局加振レベル（表 4 参照）における挙動を分析した。図 3〜6 に、積層ゴム A 及び B の水平力 $(Q)$ - 水平変形 $\left(\delta_{h}\right)$ 曲線と鉛直変形 $\left(\delta_{v}\right)-\delta_{h}$ 曲線を示 す。また、写真 $1 \sim 4$ に、各ケースの積層ゴムの破壊前及び破壊時 における変形状態について、ビデオカメラからのキャプチャー画像 を示寸。履歴曲線中のアルファベット記号は同時刻を表し、写真の 記号に対応している。これらの図、写真より、以下のことが指摘で きる。

ケース (1) : 積層ゴム A では、負側の最大変形に向かうループ（図中 ※印）において、水平変形が-40mm 付近で水平力が頭打ちとなり負 勾配が生じ始め、-80mm 付近で負勾配がさらに急となる。また、 $-80 \mathrm{~mm}$ を超えると沈み込久変形が急増している。a 点では、水平変 形が直径相当の変形 (以下直径変形と称す) を大きく超える- $104 \mathrm{~mm}$ となる。積層ゴム A では、沈み込み変形がゴム総厚の半分を超える $14 \mathrm{~mm}$ に達し、水平力が大きく低下している。なお、実験データに よれば、 $\mathrm{a}$ 点において積層ゴム $\mathrm{A}$ は重錘の全重量を支持していた。 積層ゴム B では、直径変形までは僅かにハードニングが認められる が、それを超えるとハードニングがさらに強くなる。初期状態より も鉛直荷重が小さいため、積層ゴム $\mathrm{A}$ と比べて沈み込み変形は小さ い。b 点では、積層ゴム $\mathrm{A}$ の沈み込み変形が減少し、積層ゴム $\mathrm{B}$ の 沈み込み変形が増加している。これは、重錘にロッキング振動が生 じたためであり、この結果、積層ゴム A では鉛直荷重の減少により 水平力が急増し、積層ゴム $\mathrm{B}$ では鉛直荷重の増大により水平力が急 激に低下している。 $\mathrm{b}$ 点以降は重錘のロッキング振動による鉛直荷 重変動を受け、水平変形と沈夕込夕変形が徐々に増大した。 $\mathrm{c}$ 点で は、積層ゴム $\mathrm{A}$ の沈み込み変形がゴム総厚を越える $23 \mathrm{~mm}$ となり、 写真 1 に示すように、重錘の並進運動に伴い両積層ゴムにほぼ同時 に座屈破壊が生じた。

ケース (2) $: \mathrm{a}$ 点では、水平変形が- $70 \mathrm{~mm}$ で積層ゴム $\mathrm{B}$ に引張り変形 $28 \mathrm{~mm}$ が生じている。 b 点では、水平変形が- $95 \mathrm{~mm}$ で、積層ゴム $\mathrm{B}$ に引張り変形 $27 \mathrm{~mm}$ が、積層ゴム $\mathrm{A}$ に沈み込み変形 $4 \mathrm{~mm}$ が生じて いる。また、積層ゴム $\mathrm{A}$ では水平力が頭打ちとなり、積層ゴム $\mathrm{B}$ で は水平力のハードニングが生じている。c 点では、水平変形が直径 変形を上回る- $120 \mathrm{~mm}$ となり、積層ゴム A では水平力が急激に低下 し、積層ゴム B ではハードニングがさらに急峻となった。d点では、 水平変形がほぼ維持された状態で、積層ゴム $\mathrm{B}$ の引張り変形が $14 \mathrm{~mm}$ に達した時点で、積層ゴム B のうち、写真 2 に示したゴムと は反対側のゴムに引張り破断が生じた。 $\mathrm{a}$ 点や $\mathrm{b}$ 点と比較して $1 / 2$ 程度の小さい引張り変形での破断となったが、これは水平変形が $\mathrm{a}$ 点や $\mathrm{b}$ 点と比較して大きく、積層ゴムの引張り破断に対する変形能 力が低下していたためである10)。

ケース (3): $\mathrm{a}$ 点では、水平変形が-70mm 程度で、積層ゴム $\mathrm{A}$ に $4 \mathrm{~mm}$ 程度の沈み込み変形が、積層ゴム $\mathrm{B}$ に $4 \mathrm{~mm}$ 程度の引張り変形が生 じている。 $\mathrm{b}$ 点では、水平変形が直径変形を僅かに超え- $95 \mathrm{~mm}$ とな り、積層ゴム $\mathrm{A}$ では、沈み込み変形がゴム総厚の半分に近い $10 \mathrm{~mm}$ に達し、水平力が大きく低下している。積層ゴム B では沈み込み変 形が $1 \mathrm{~mm}$ 程度で、水平力にハードニングが生じている。 $\mathrm{b}$ 点の状 況はケース(1)の a 点とほぼ似たような状況であるが、ケース(1)より も水平変形が小さく、積層ゴム $\mathrm{A}$ の水平力の低下が小さいため、水 

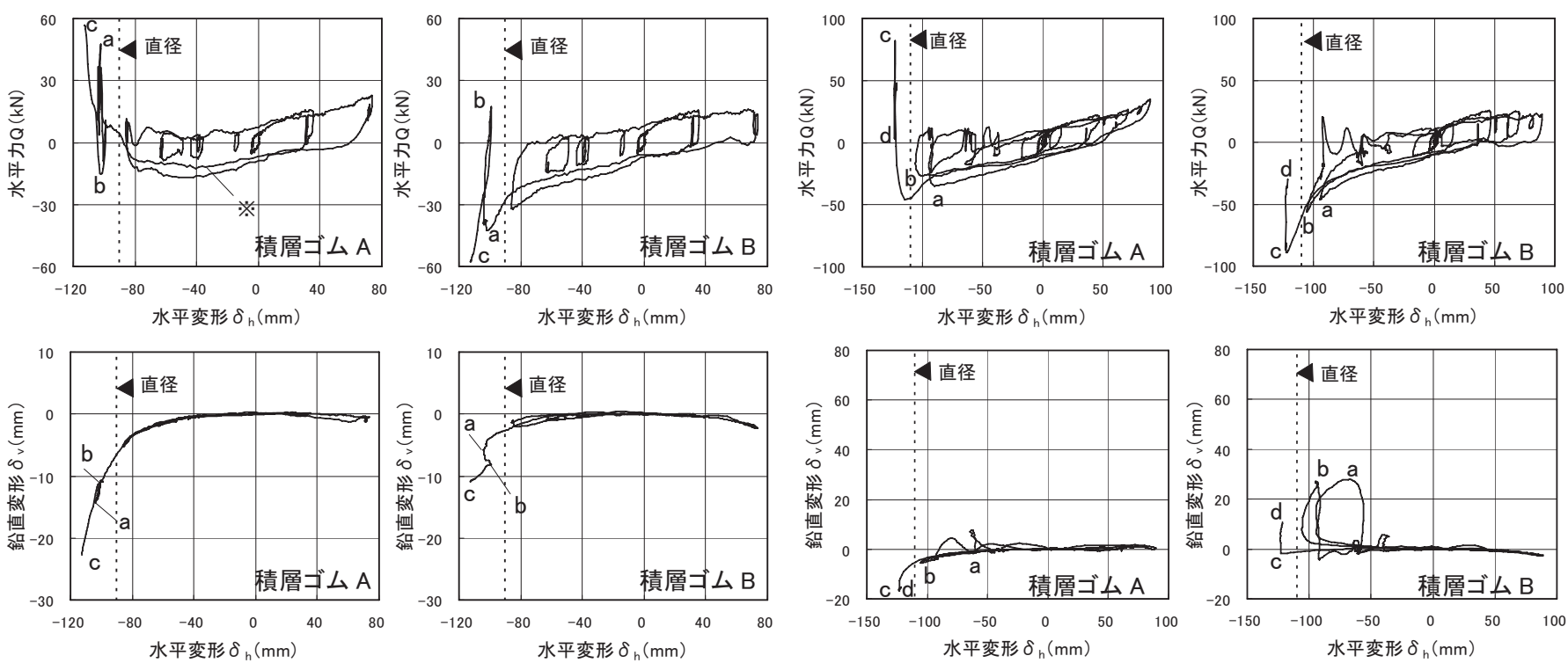

図 3 積層ゴム破壊時の履歴特性（ケース (1)
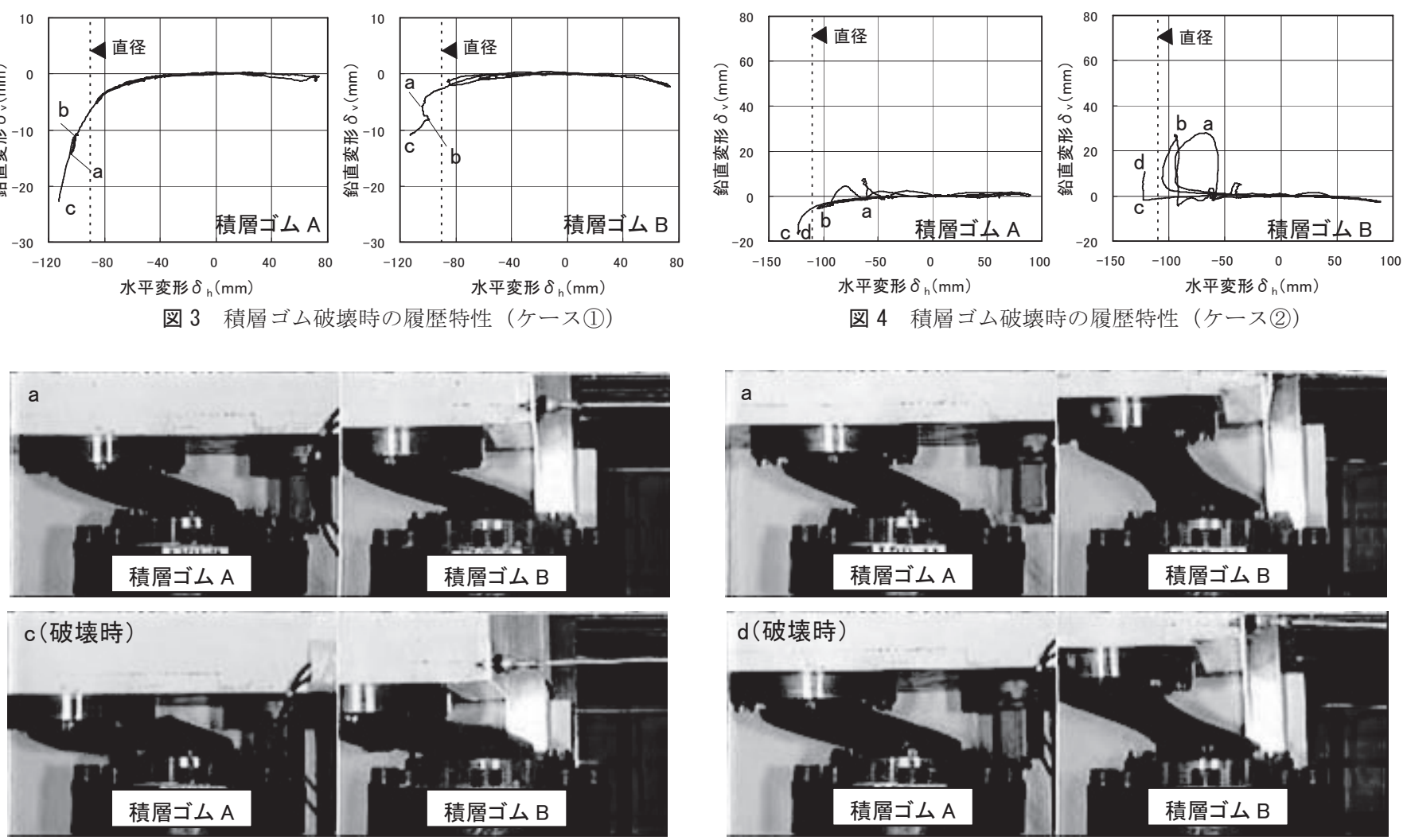

図 4 積層ゴム破壊時の履歴特性（ケース(2)）
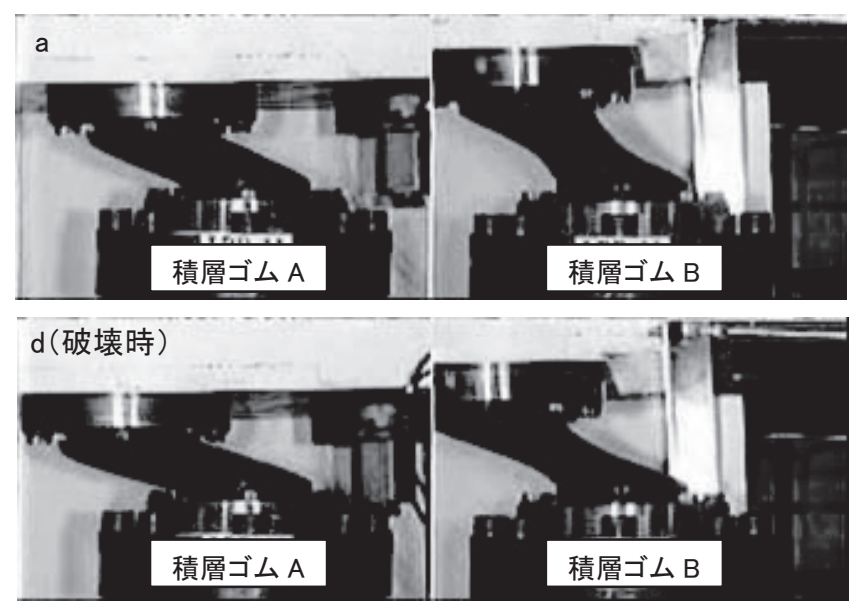

写真 2 積層ゴム破壊時の状況（ケース(2)）

平変形が直径変形を超えたにもかかわらず、その直後に破壊するこ となく再び原点まで変形が復帰した。 b 点以降は、ケース(1) と同様 に重錘のロッキング振動を伴いながら、水平変形が増大した。水平 変形が $110 \mathrm{~mm}$ を超えた $\mathrm{c}$ 点において、積層ゴム $\mathrm{A}$ の水平力がさら に大きく低下し、沈み込み変形が $21 \mathrm{~mm}$ となり、写真 3 に示すよう に両積層ゴムにほぼ同時に座屈破壊が生じた。

ケース(4)：図6では、浮き上がり挙動を明確にするため、破断直前 の 1 ループが明瞭になるように表示している。a 点では、負側水平 変形が- $91 \mathrm{~mm}$ で最大となる。積層ゴム $\mathrm{A}$ の沈み込み変形は $3 \mathrm{~mm}$ 程 度、積層ゴム $\mathrm{B}$ の引張り変形は $6 \mathrm{~mm}$ 程度である。次に、 $\mathrm{b}$ 点に向 かうループにおいて、積層ゴム $\mathrm{B}$ の引張り変形が急増して $33 \mathrm{~mm}$ に達する。この間、水平変形は僅かに減少して $75 \mathrm{~mm}$ となっており、 重錘の運動としては積層ゴム $\mathrm{A}$ 側を支点として積層ゴム $\mathrm{B}$ 側が浮上 する回転運動である。c 点において、積層ゴム $\mathrm{B}$ の引張り変形ほぼ ゼロとなるが、積層ゴム $\mathrm{A}$ に引張り変形が生じ始めており、重錘が 積層ゴム $\mathrm{B}$ 側での着地と同時に積層ゴム $\mathrm{A}$ 側で浮上している。d 点 では、正側水平変形が $95 \mathrm{~mm}$ で最大となる。積層ゴム $\mathrm{A}$ の引張り 変形は $21 \mathrm{~mm}$ 程度、積層ゴム $\mathrm{B}$ の沈み込み変形は $3 \mathrm{~mm}$ 程度である。

$\mathrm{d}$ 点から e 点おいては、積層ゴム $\mathrm{B}$ の a 点から b 点で見られた挙動 と同様に、積層ゴム $\mathrm{A}$ では水平変形が減少しつつ引張り変形が急増 した。最終的には、写真 4 に示寸ように $\mathrm{e}$ 点で積層ゴム $\mathrm{A}$ に引張り 破断が生じた。破断時における水平変形は $44 \mathrm{~mm}$ 、引張り変形は $57 \mathrm{~mm}$ である。ケース(2) と比較して破断時の引張り変形が大きいの は、ケース(2)よりも水平変形が小さく、積層ゴムが引張り破断に対 してより大きな変形能力を有していたためである 10)。積層ゴム A が 破断した後は正側に水平変形が急増し、積層ゴム $\mathrm{B}$ に座屈破壞が生 じた。

\section{4 終局挙動を支配する要因}

ケース (1)とケース (3)では積層ゴムに座屈破壊が、ケース(2)とケー ス(4)では積層ゴムに引張り破断が生じた。これらの破壊形式を決定 づける要因として、免震層の水平復元力特性と剛体の静的浮き上が り限界水平力 $Q_{u p}$ に着目した。剛体の静的浮き上がり限界水平力と は、水平面上に置いた剛な直方体の重心に水平力を静的に作用させ、 直方体が圧縮端を回転中心にして浮き上がり始め、反力がゼロとな った瞬間の水平力である。重錘の重量を $W$ とすれば $Q_{u p}$ は次式で定 義される。 

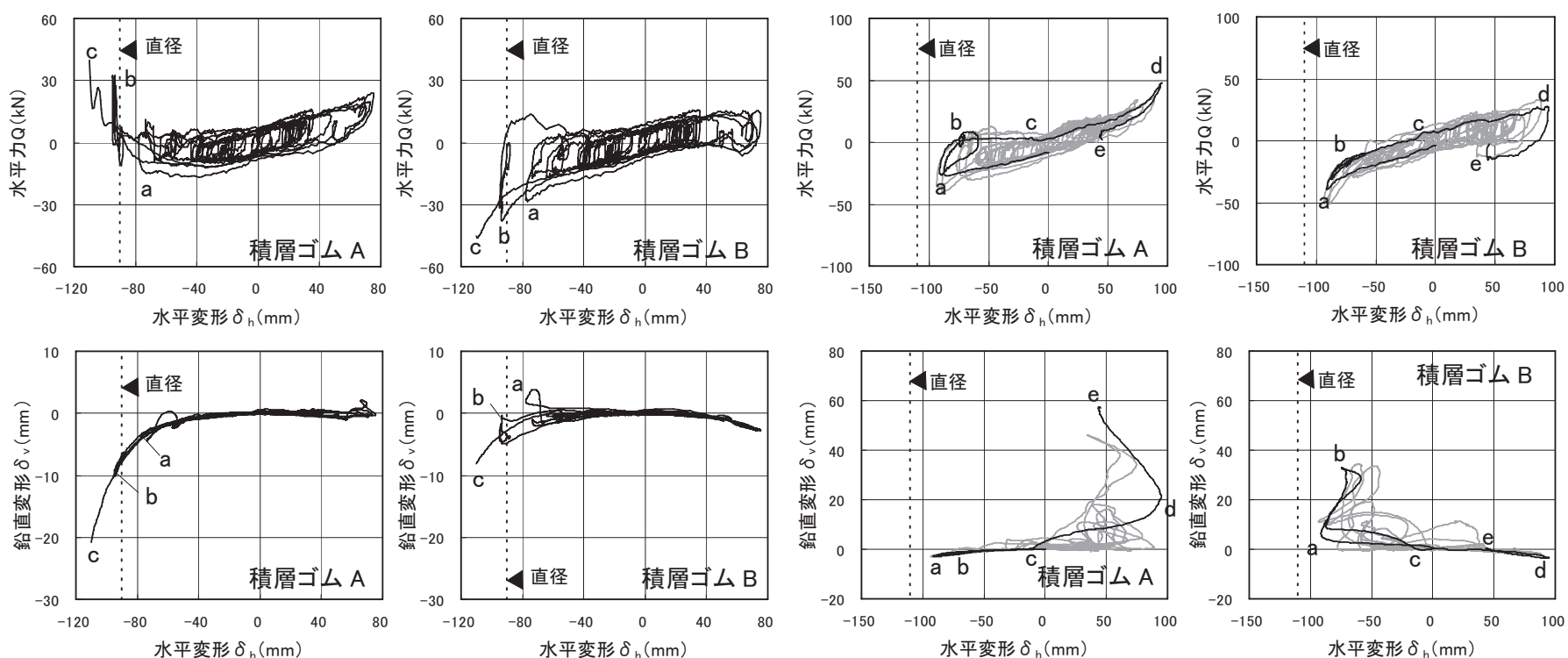

図 5 積層ゴム破壊時の履歴特性（ケース(3)）

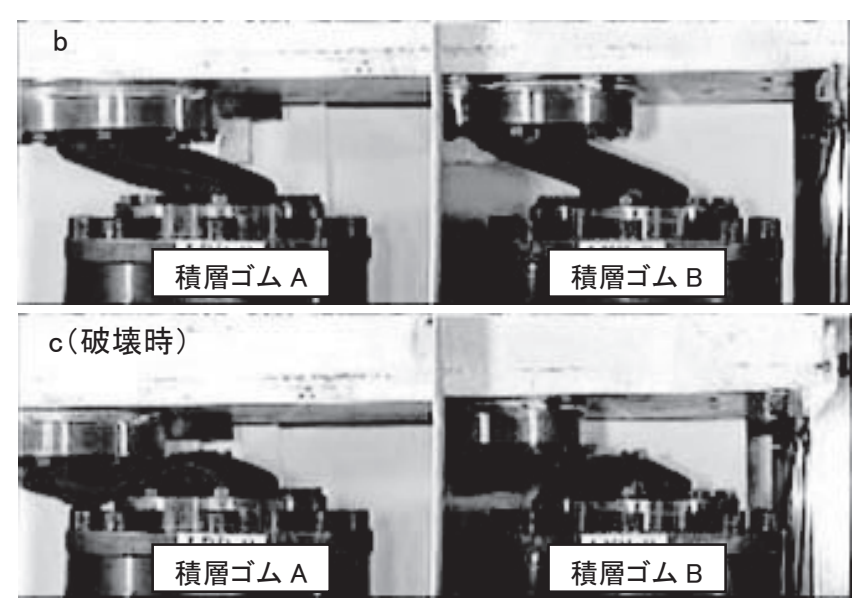

写真 3 積層ゴム破壞時の状況（ケース(3)）

$$
Q_{u p}=\frac{W}{(H / B)}
$$

重鍾が浮き上がり積層ゴムに引張り変形が生じる場合の条件は、免 震層水平力を $Q_{h}$ とすれば次式で表される ${ }^{1)}$ 。

$$
Q_{h}>Q_{u p}
$$

図 7 に、各ケースについて、終局加振レベルにおける免震層水平力 $\left(Q_{h}\right)$ - 水平変形 $\left(\delta_{h}\right)$ 曲線を示す。図中には $Q_{u p}$ を示している。 $Q_{u p}$ の值を(1)式より計算すると、ケース(1)、(2) ( $\left.\mathrm{H} / \mathrm{B}=4\right)$ では $48 \mathrm{kN}$ 、 ケース (3)、(4) $(\mathrm{H} / \mathrm{B}=6)$ では $32 \mathrm{kN}$ である。これらの図より、以下 のことが指摘できる。

ケース(1)、(3) : 免震層水平力は、水平変形の増大に伴いその増加率 が小さくなり、直径変形付近においてほぼ頭打ちとなる。これは、 図 3 と図 5 に示すように、大変形域において積層ゴム $\mathrm{A}$ の水平力が 大きく低下しているためである。また、免震層水平力は、ケース (1) では常に $Q_{u p}$ 以下であり、ケース(3)でも最大変形に至る手前の変形 域において一部 $Q_{u p}$ を超えているが概ね $Q_{u p}$ 以下である。最終的に 積層ゴムに破壊が生じるのは、水平変形が直径変形を超えた後であ

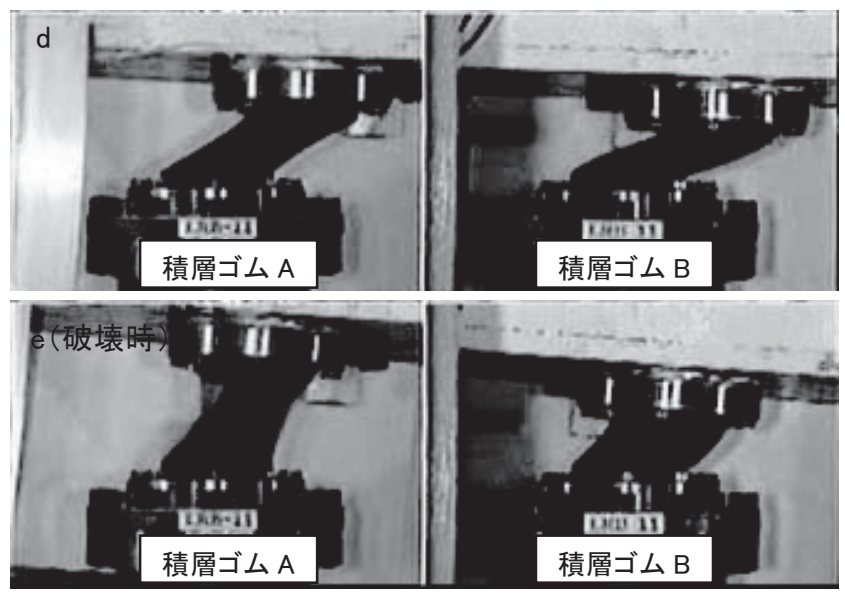

写真 4 積層ゴム破壊時の状況（ケース(4)）
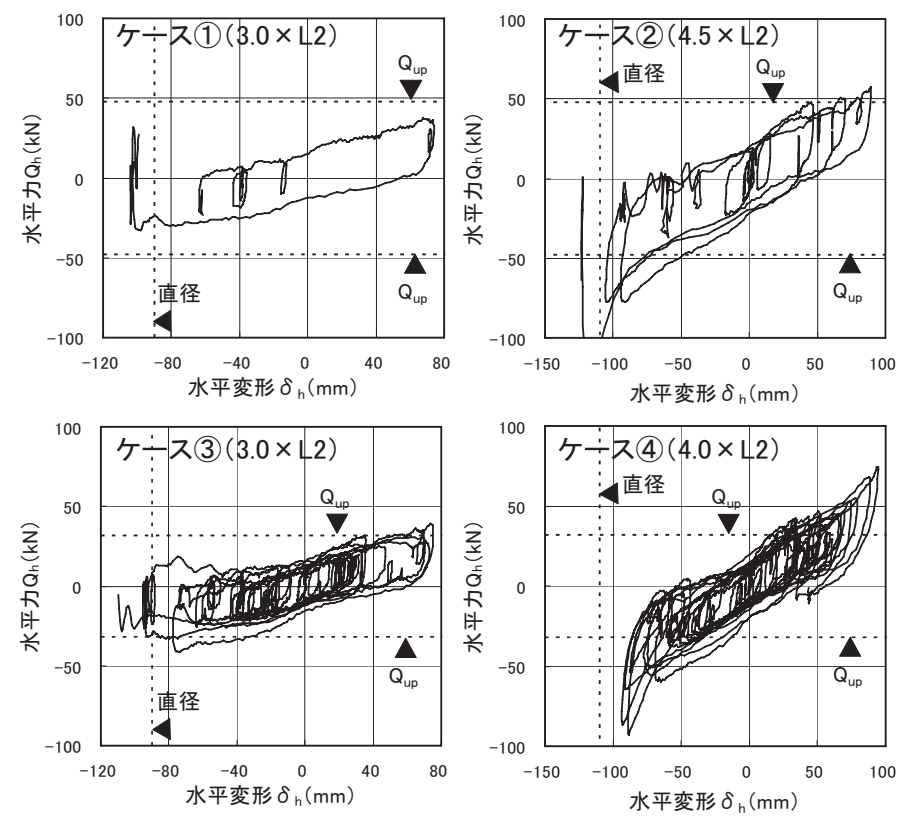

図 7 免震層水平力 $\left(\mathrm{Q}_{\mathrm{h}}\right)$ - 水平変形 $\left(\delta_{\mathrm{h}}\right)$ 曲線 
り、このことが積層ゴムに座屈破壊が生じて終局となる場合の判断 基準となる。また、ケース(1)とケース(3)は塔状比が異なるケースで あるが、3.2 項で述べたとおり、終局加振レベルまでの両者の応答 最大值に大きな違いは認められない。さらに、終局加振レベルはと もに等しく、図 7 の $Q_{h}-\delta_{h}$ 曲線の形状は類似したものになっている。 免震層水平力が $Q_{u p}$ を超えることなく、終局挙動として積層ゴムの 座屈破壊が生じる場合、上部構造の塔状比が終局までの挙動に与え る影響は小さいと言える。

ケース (2)、(4): 両ケースともに免震層水平力が $Q_{u p}$ を上回っている 部分が多数認められる。また、図 4、6 から分かるように、それら にほぼ対応して、積層ゴムに引張り変形が生じている。免震層水平 力が $Q_{u p}$ を超える水平変形を比較すると、ケース(2)の方がケース (4) よりも大きい。このため、ケース(2)では直径変形に近い水平変形下 において引張り変形が、ケース(4)では直径の半分以下の水平変形下 において引張り変形が生じた。一方、免震層水平力が $Q_{u p}$ を超え引 張り変形が生じてもすぐに引張り破断が生じるわけではなく、破断 まである程度の余裕を有していることが分かる。引張り破断に対す る余裕度は、小変形域で引張り変形が生じたケース(4)の方が大きい。 これは、小変形域では引張り破断に対する变形能力が向上し、積層 ゴムはより大きな引張り変形を許容できるためである ${ }^{10) 、 こ の こ と ~}$ は、ケース(2)とケース(4)の終局加振レベルが概ね同程度となってい る要因の一つである。実験では引張り変形能力に優れた縮小試験体 を用いているため、引張り変形が生じた後の引張り破断までの余裕 度を定量的に評価することは難しい。しかしながら、本実験から得 られた結果は、免震層水平力が $Q_{u p}$ を超え積層ゴムに引張り変形が 生じた後も、その時点における水平変形に応じて引張り破断までの 変形余裕度を有していること、塔状比が大きくなっても、積層ゴム に引張り破断が生じる入力レベルが著しく低下寸るわけではないこ とを示唆している。

以上より、免震建物の終局挙動は免震層水平力と剛体の静的浮き 上がり限界水平力 $Q_{u p}$ との大小関係に支配されている。すなわち、 免震層水平力が $Q_{u p}$ 以下であれば、積層ゴムに引張り変形が生じる ことはなく、免震層水平変形が直径相当の変形を超えた場合に、積 層ゴムに座屈破壊が生じる。一方、免震層水平力が $Q_{u p}$ を超えると、 積層ゴムに引張り変形が生じ、入力レベルが大きくなると引張り破 断が生じる可能性が高くなる。

\section{4. 実免震建物への適用}

本実験の結果を実免震建物の終局挙動に適用寸るため、以下の検 討を行った。天然ゴム系積層ゴムとダンパを用いた免震構造の設計 では、免震層水平力 $Q_{h}$ は次式で与えられる。

$$
Q_{h}=\left(\frac{2 \pi}{T}\right)^{2} \frac{W}{g} x+Q_{y}
$$

ここで、 $T$ は免震周期、 $x$ は免震層水平変形、 $g$ は重力加速度、 $Q_{y}$ はダンパの降伏せん断力である。（3)式を $\mathrm{W} て ゙$ て余して、 $T=3 、 4 、 5 \mathrm{~s}$ について示したのが図 8 である。ここでは $Q_{y} / W=0.03$ としている。 図中の点線は、実験と同じく建物幅内に積層ゴムを 2 個配置とし、 各 $\mathrm{H} / \mathrm{B}$ に対応する $Q_{u p} / W$ を(1)式より求めたものである。これより、 $\mathrm{H} / \mathrm{B}$ が 3 以下であれば、 $T$ を $4 \mathrm{~s}$ 以上に寸ることで $Q_{h}$ は $Q_{u p}$ を超え ることがなく、終局挙動として積層ゴムの座屈破壊が想定される。
一方、 $T$ を $4 \mathrm{~s}$ 以上としても、H/B が 4 以上であれば、大変形域にお いて $Q_{h}$ が $Q_{u p}$ を超える場合もあり、終局挙動として積層ゴムの引張 り破断が生じる可能性がある。以上の検討では、簡単のために免震 層水平力を線形としているが、実際の設計では、積層ゴムにはその 形状と面圧に応じて大変形時に水平力の低下やハードニングが生じ るため、免震層水平力は複雑な非線形挙動を呈する。従って、終局 挙動をより正確に捉えるためには、それらの影響についても考慮す ることが望ましく、これについては今後の検討課題である。また、 建物幅内に配置する積層ゴムの個数を増加させる場合、 $Q_{u p}$ がさら に小さくなることにも留意する必要がある ${ }^{11)}$

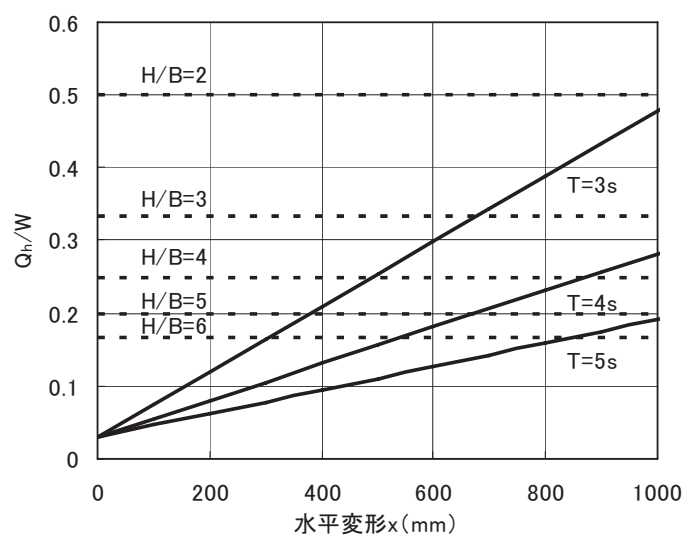

図 8 免震層水平力と $\mathrm{Qup}$ の関係

\section{5. 結論}

免震建物の破壊時における終局挙動の解明を目的とし、積層ゴム で支持した塔状免震建物の振動台実験の結果より、積層ゴムが破壊 した時の上部構造と積層ゴムの詳細な挙動について分析した。積層 ゴム破壊時における挙動は、積層ゴムが座屈破壊するタイプと積層 ゴムが引張り破断するタイプに分けられ、それぞれの挙動の特徽は 以下の通りまとめられる。

座屈破壊 : 加振レベルが大きくなると、過大な圧縮荷重を受ける側 （圧縮側）の積層ゴムの復元力特性に負勾配が生じたが、終局加振 レベルまで免震効果が保たれていた。終局時には、圧縮側の積層ゴ ムの水平力が大きく低下し、その後生じたロッキング振動によりも う一方の積層ゴムの水平力も低下した。この結果、免震層全体とし て復元力を失い、重錘の並進運動に伴い両積層ゴムにほぼ同時に座 屈破壊が生じた。免震層の水平力は常に浮き上がり限界水平力 $Q_{u p}$ 以下であり、最終的に破壊が生じたのは、水平変形が積層ゴムの直 径相当の変形を超えた後であり、このことが座屈破壊の生起に対す る一つの判断基準となる。また、塔状比の違いにより、終局加振レ ベルまでの応答最大值や積層ゴム破壊時の履歴特性に大きな違いは 認められなかった。

引張り破断 : 免震層水平力が $Q_{u p}$ を超えると、一方の積層ゴムを支 点として他方が浮き上がり、積層ゴムに引張り変形が生じた。加振 レベルが大きくなると、重錘の回転運動がさらに顕著になり、最終 的に引張り破断が生じた。また、塔状比の違いにより加速度や変形 には有意な差が認められたが、終局加振レベルは同程度となった。 
これは、塔状比が大きくなると、引張り変形能力の大きい小変形域 で引張り変形が生じやすくなり、破断時の引張り変形が大きくなっ たためである。このことは、積層ゴムに引張り変形が生じた後もそ の水平変形に応じて引張り破断までの変形余裕度を有していること、 塔状比が大きくなっても、積層ゴムが引張り破断する入力レベルが 著しく低下寸ることはないことを示唆している。

以上の実験結果を受け、通常の免震設計で用いられる免震層水平 力の計算值を $Q_{u p}$ と比較し、実免震建物における終局挙動を評価し た。これより、塔状比が 3 以下であれば、免震周期を $4 \mathrm{~s}$ 以上に設 定することで積層ゴムに座屈破壊が生じる可能性が高くなること、 $T$ を $4 \mathrm{~s}$ 以上としても塔状比が 4 以上であれば、大変形域において引 張り破断が生じる可能性があることが確認された。ただし、ここで の検討は免震層水平力を線形としているため、終局挙動をより正確 に捉えるためには、大変形時における積層ゴムの水平力の低下や八 ードニングの影響についても考慮することが望ましく、今後の検討 課題である。

\section{謝辞}

振動台実験の実施に際して、元鹿島建設株式会社の故飯塚真巨氏、 故吉川和秀氏には多くの有益な助言をいただきました。また、本論 文作成にあたり、京都大学防災研究所の中島正愛教授には多大なご 指導を賜りました。ここに感謝の意を表します。

\section{参考文献}

1）高岡栄治、二村有則、飯塚真巨、竹中康雄、吉川和秀 : 積層ゴムで支持し た塔状免震建物の終局挙動に関する振動台実験、日本建築学会構造系論文 集、第 605 号、pp.87-93、2006.7.

2) 4）竹中康雄、飯塚真巨、二村有則、吉川和秀、高岡栄治：塔状免震建物 の終局挙動に関する振動台実験（その 1) 〜 (その 3)、日本建築学会大会 学術講演梗概集 B-2、pp.783-788、1999.9.

5）飯塚真巨、二村有則、竹中康雄、吉川和秀、高岡栄治 : 塔状免震建物の終 局挙動に関する振動台実験（その 4)、日本建築学会大会学術講演梗概集 B-2、pp.645-650、2000.9.

6) Kato M, Watanabe Y, Kato A, Koshida H, Mizukoshi K, Fukushima Y, Nojima O, Yoneda G, Onimaru S: Dynamic breaking tests on base-isolated FBR plant, 12th SMiRT, Vol.K2, pp.267-272, 1993.

7）猿田正明、田村和夫、菊池優 : 積層ゴムに引張り軸力を生じる免震架構の 振動実験、日本建築学会大会学術講演梗概集 B-2, pp.669-670、1997.9

8) 久野雅祥、長島一郎、欄木龍大、富島誠司、飯島昭治 :「複合免震構法の高 さ幅比の大きい建物への適用に関する実験的研究（その 1 振動台実験）、 日本建築学会大会学術講演梗概集 B-2、pp.603-604、1998.9.

9)三山剛史、増田圭司：積層ゴムを用いたアスペクト比の高い免震建物の振 動台実験 積層ゴムに生じる引張力とその後の着座による振動性状、日本 建築学会構造系論文集、第 573 号、pp.61-68、2003.11.

10)高山峯夫 : 免震構造用天然ゴム系積層ゴムアイソレータの限界性能、日本 建築学会技術報告集、第 1 号、pp.160-165、1995.12.

11)多田英之、高山峯夫他 : 4 秒免震への道一免震構造設計マニュアルー、 pp.31-32、理工図書、1997. 